\title{
Sensory evaluation of rice fortified with iron
}

\author{
Análise sensorial de arroz fortificado com ferro \\ Mark Anthony BEINNER ${ }^{1 *}$, Anne Danieli Nascimento SOARES ${ }^{2}$, \\ Ana Laura Antunes BARROS², Marlene Azevedo Magalhães MONTEIRO 3
}

\begin{abstract}
The objective of this study was to examine sensory differences between conventional rice and iron-fortified Ultra Rice rice (UR) and determine consumer acceptance. Differences between both types of rice were analyzed using the Duo-Trio Test on 37 non-trained judges. The Acceptance Test evaluated general rice appearance, color, aroma and taste by 43 non-trained judges, using a 7-point hedonic scale with extremes ranging from "really disliked" and "really liked." There were no significant differences between the analyzed samples of conventional rice and UR rice using Duo-Trio Test. Mean values from the Acceptance Test for the evaluated attributes (general appearance, color, aroma e taste) were 5.6 and 5.9, corresponding to "liked" and "really liked" according to the hedonic scale, respectively. The iron did not alter the sensory characteristics of the final product, and the iron-fortified rice was well accepted.

Keywords: rice; fortification with iron; sensory evaluation.
\end{abstract}

\section{Resumo}

O objetivo deste trabalho foi verificar diferenças sensoriais entre o arroz convencional e o arroz fortificado com ferro e determinar a aceitação deste pelo consumidor. As diferenças entre os dois tipos de arroz foram analisadas por meio do teste Duo-Trio, com 37 julgadores não treinados. O Teste de Aceitação avaliou aparência geral, cor, aroma e sabor do arroz fortificado com 43 julgadores não treinados, utilizando escala hedônica de sete pontos, com extremos "desgostei muitíssimo" e "gostei muitíssimo". Não houve diferenças significativas entre as amostras analisadas pelo Teste Duo-Trio. Os valores médios obtidos no Teste de Aceitação para os atributos avaliados (aparência geral, cor, aroma e sabor) foram entre 5,6 e 5,9; correspondentes a "gostei" e "gostei muito" de acordo com a escala hedônica. O ferro não causou alterações às características sensoriais do produto final, e o arroz fortificado foi bem aceito.

Palavras-chave: arroz; fortificação com ferro; avaliação sensorial.

\section{Introduction}

Rice is a common food staple consumed by diverse societies and represents the basis of diet for more than half of the world's population. Brazil is one of the major producers of cereal grains and the largest in South American. It produced approximately 10 million tons. in 2003 (FOOD AND AGRICULTURE ORGANIZATION OF THE UNITED NATIONS, 2004). According to research on Family Incomes carried out by the Brazilian Institute of Statistics and Geography (INSTITUTO BRASILEIRO DE GEOGRAFIA E ESTATÍSTICA, 2004), the average amount of household rice consumption was approximately $25 \mathrm{~kg} /$ person/year. The easy cultivation of rice, its conservation and transportation, high yield, low cost, high nutritional value, and countless forms of utilization are just some of the many characteristics that make rice so popular and appreciated by different cultures (PHILIPPI, 2003). According to Philippi (2003), rice constitutes an excellent source of carbohydrates and energy in addition to vitamins such as thiamin, riboflavin, and niacin; however, iron is not a significant component of the white rice popularly consumed in this country (UNIVERSIDADE ESTADUAL DE CAMPINAS, 2006).

The fortification of foods with nutrients is an accepted practice which has been employed by food industries since the second half of the $20^{\text {th }}$ century (REILLY, 1996) aiming at increasing the nutritional value and prevent or correct one or more nutrient deficiencies (BRASIL, 1998).

Today, with the advance of technology, rice can be an efficient option as a vehicle for fortification of iron as a way to minimize the prevalence of iron deficiency anemia, which represents, world-wide, a hegemonic nutritional problem in public health terms affecting, principally, children and reproductive aged women (WORLD HEALTH ORGANIZATION, 2001). In Brazil, iron deficiency anemia has shown the tendency to assume epidemic proportions over the last decades (OLIVEIRA et al., 2002; MONTEIRO; SZARFARC; MONDINI, 2000).

Recebido para publicação em 15/8/2008

Aceito para publicação em 8/7/2009 (003784)

${ }^{1}$ Departamento de Enfermagem Materno Infantil e Saúde Pública, Universidade Federal de Minas Gerais - UFMG, CEP 30130-100, Belo Horizonte - MG, Brasil,

E-mail: mark@enf.ufmg.br

2 Universidade Federal de Minas Gerais - UFMG, CEP 30130-100, Belo Horizonte - MG, Brasil

${ }^{3}$ Departamento de Enfermagem Aplicada, Universidade Federal de Minas Gerais - UFMG, CEP 30130-100, Belo Horizonte - MG, Brasil

${ }^{*}$ A quem a correspondência deve ser enviada 
Fortification or enrichment are efficient means for reaching out to targeted populations without the need for cooperation of individuals, therefore making them easy, safe, inexpensive, and effective ways of solving, in short and middle terms, minor nutrient deficiencies (FERREIRA, 2000).

However, Hurrel (2002) states that some technical difficulties can arise when adding this nutrient to foods because the selected type of iron can interfere with the sensory characteristics of the final product (food matrix). Thus, sensory tests can detect small and perceptive alterations by human senses, which oftentimes can not be verified by other analytic procedures, and assess the impact on acceptance of the product by the consumers (CARDELLO, H. M. A. B.; CARDELLO, L., 1998).

Sensory analysis is a scientific method to identify sensory properties of food using human senses: vision, hearing, smell, taste, and touch (DUTCOSKY, 1996). The test must be included as a guarantee of the quality of foods to be an intergraded multidimensional means and possess important advantages such as, to determine the acceptance of a product, in part, by consumers (CARDELLO, H. M. A. B.; CARDELLO, L., 1998). Therefore, the objective of this work was to verify the sensory differences between conventional rice and iron-fortified Ultra Rice (UR) and its acceptability by the consumers with the intention to test the latter for commercialization in the Brazilian market.

\section{Materials and methods}

The tested rice was type 1, polished, long-grain, and it was manufactured by Camil Foods Company (Blumenau - SC). The fortified cereal (UR) was formulated with the addition of ferric pyrophosphate (Aksell Quimica Ltda., São Paulo) according to the process proposed by Hotz et al. (2008). Firstly, the iron-fortified rice was prepared by adding iron fortifier and other stabilizing ingredients to rice flour. The dough prepared from this mixture was extruded (using the same extrusion process used to make pasta), cut to form rice-shaped grains, and then dried. The extruded grains were manufactured by Camil Foods, Ltd., Sao Paulo, Brazil. The resulting rice product was an enriched composition of $46.7 \mathrm{mg}$ of iron/100 $\mathrm{g}$ of rice grains.

\subsection{Sample preparation}

The following ingredients and quantities were used to prepare both types of rice for the two sensory tests (described below): Oil, $11 \mathrm{~mL}$; garlic, $5 \mathrm{~g}$; salt, $10 \mathrm{~g}$; rice, $500 \mathrm{~g}$; hot water, $1250 \mathrm{~mL}$; and cold water, $560 \mathrm{~mL}$.

\subsection{Sensory analysis}

The sensory evaluation of rice was conducted in two parts. The first part had the objective of verifying the differences between UR rice and conventional, commercially sold white grain rice donated by the manufacturer. For this purpose, the Duo-Trio Sensory Test was applied under controlled conditions (MORAES, 1988; MEILGAARD; CIVILLE; CARR, 2006) using individual cabins at the Laboratory of Dietetics at the School of Nutrition of the Federal University of Minas Gerais - UFMG.
The cabins were illuminated with white light designed to avoid masking visual differences between the tested products. Thirtyseven untrained panelists of different gender and age groups were recruited from the University community (students, staff, and professors). Once inside the cabins, the panelists received a standard rice sample ( $20 \mathrm{~g})$ and two unknown $(20 \mathrm{~g})$ samples of rice; one was the same as the standard rice sample and the other was the fortified rice sample. All samples were served on white plastic plates.

The three samples were arranged side by side on white polyethylene trays (INTERNATIONAL STANDARD ORGANIZATION, 1982). The standard sample was identified as "P" and the other two were coded with 3 random algorithms. The panelists were instructed to taste the plates containing rice samples from left to right, and between each sample plate, to drink water at room temperature to minimize the influence of the residue present on taste buds. Each panelist received an evaluation form (Figure 1) in which they should circle the sample number they considered equal to the standard rice sample. The probability of having chosen right or wrong choices, that is, to indicate correctly, which unknown sample was equivalent to the reference sample was equal to 0.5 .

The objective of the second part of this study was to verify the acceptance of UR rice by volunteers who reside in the city of Vespasiano, Minas Gerais, the same population of participants of an earlier, randomized study that evaluated iron deficiency, and who benefited from participating by receiving donations of UR rice for 5 months.

To test for acceptability (MEILGAARD; CIVILLE; CARR, 2006), 43 untrained volunteer participants of different backgrounds (age, gender, and professions), were recruited randomly from five health clinic locations of the city. The rice was prepared in a kitchen at the community center, and the sample tasting was conducted in a well illuminated white lighting room, with a table and some chairs. There was no communication among the participants during the test.

Each participant was served a $20 \mathrm{~g}$ sample of cooked rice in a white small plastic bowl, a plastic fork, and an evaluation form (Figure 1) to rate four attributes: general appearance, color, aroma, and taste according to (INTERNATIONAL STANDARD ORGANIZATION, 1982) instructions. A 7-point hedonic verbal scale (MINIM, 2006) was used which contained extremes that indicated "very much disliked" (1) to "liked very much" (7). This study was approved by the Human Ethics Committee at the

Use the number scale below to mark which number that you liked
or disliked about the rice.
$\begin{array}{ll}7 \text { - Very much liked } & \text { ( ) General appearance } \\ 6 \text { - Liked a lot } & \text { ( ) Taste } \\ 5 \text { - Liked } & \text { ( ) Smell } \\ 4 \text { - Liked and did not like } & \text { ( ) Color } \\ 3 \text { - Disliked } & \\ 2 \text { - Much disliked } & \\ 1 \text { - Very much disliked } & \end{array}$

Figure 1. Duo-Trio Test evaluation form. 
UFMG (ETIC 238/06) and followed strict norms of the 196/96 resolution of the Brazilian Ministry of Health.

\subsection{Statistical methods}

A statistical analysis of the Duo-Trio Test was conducted according to Meilgaard, Civille and Carr (2006), which considered the minimum number of coincident responses using a mono-caudal comparison with a 5\% significant level. In the Acceptance Test, the means were calculated for each attribute in addition to the global mean for the product. The attributes general appearance and color are considered to directly influence consumer decision to purchase a product and, consequently, to consume it (FERREIRA, 2000b).

\section{Results and discussion}

The results of the Duo-Trio Test showed that among the 37 participants, 18 correctly identified the sample as being equal to the reference sample. To achieve $5 \%$ significance, 24 responses were necessary for the mono-caudal comparison to show a significant difference between the two types of rice (UR rice and conventional, non-fortified rice).

Fourteen participants wrote down commentaries on their evaluation sheets as follows; $42.8 \%(n=6)$ stated that there were many similarities between samples; 7.1\% $(\mathrm{n}=1)$ commented that the sample was well accepted; $21.4 \%(n=3)$ said that there was a noticeable taste in one of the samples; $21.4 \%(\mathrm{n}=3)$ detected an alteration in texture, and $21.4 \%(\mathrm{n}=3)$ observed a color difference.

The Duo-Trio Test is a discriminative method, and it has been used in studies to determine if there are noticeable differences between foods when their ingredients, processing, packaging, or storage are somehow changed (DUTCOSKY, 1996). The results of this study demonstrate that the enrichment of food products (in this case iron added to rice), consumed on a daily basis, may not cause significant impacts on the cultivation and food habits. Therefore, the production and industrial commercialization of such products may become an attractive option.

The Acceptance Test is useful if one desires to investigate the consumer behavior in relation to products (MEILGAARD; CIVILLE; CARR, 2006). In this test, the means and standard deviations (SD) results for general appearance, color, odor, and taste are shown in Table 1. The panelists' ratings were between "liked" and "liked a lot." This result was also rated between "liked" and "liked a lot" on the test scale (Figure 1).

The evaluated food attributes were positively rated in addition to being well accepted. In spite of some perceptional differences observed in the Duo-Trio Test by a small number of panelists $(\mathrm{N}=9)$, namely color and texture, this fact did not

Table 1. Mean and standard deviation $( \pm S D)$ of attribute values recorded by evaluators according to each analyzed characteristic.

\begin{tabular}{ccccc}
\hline Attributes & General appearance & Color & Odor & Smell \\
\hline Mean \pm SD & $6.0 \pm 1.4$ & $5.8 \pm 1.2$ & $5.9 \pm 1.2$ & $5.6 \pm 1.5$ \\
\hline
\end{tabular}

interfere with a favorable product acceptance. Therefore, there was no significant difference between the analyzed samples and between the graded attributes in the descriptive sensory analysis for visual, smell, and taste characteristics demonstrating that the UR rice showed favorable acceptance.

The composition of ferric pyrophosphate has the advantage of not causing interferences in the sensory characteristics of food (HURREL, 1997), due to its low solubility (SALGUEIRO, 2002; HURRELL, 1997), and it presents white coloration (NABESHIMA et al., 2005). From a nutritional point of view, this iron salt presents the disadvantage of variable absorption, as it dissolves very slowly under a normal acid concentration of the stomach (HURRELL et al., 1989) presenting 21 to 74\% bioavailability according to data presented by Hurrell (1997). On the other hand, more soluble compounds can cause fat oxidation (i.e., rancidity) and also induce changes in color within 6 months of storage. Reduced irons are preferred, and the smaller the particle size, the better it will be absorbed (ALLEN; GILLESPIE, 2001).

A study conducted by Nabeshima et al. (2005) investigated the technological and sensory properties of fortified different kinds of bread with different iron sources and compared them to conventional bread. To evaluate the appearance, smell, taste, and texture attributes, a nine point hedonic scale was used. No significant detectable differences were observed between the enriched samples and the standard ones comparing the measurements obtained in the study, mainly consumer acceptance. However, it was observed that samples containing ferric pyrophosphate (4.2 mg Fe.100 $\mathrm{g}^{-1}$ of flour) resulted in a fluffier bread. Thus, in the present study, the UR rice fortified with ferric pyrophosphate presented a differentiated texture, more moist, which does not interfere with consumer acceptance.

Yet, in another study on sensory characteristics, Moretti et al. (2005) evaluated rice fortified with ferric pyrophosphate using different particle sizes (ranging from 0.5 to $2.5 \mu$ ) and at various concentrations ( 0.5 to $1 \%$ ) using the triangular sensory analysis tests involving 18 panelists. The results suggest that the differences between the conventional and fortified cereals were minimal since less than half of the panelists detected differences, results similar to those found in the Duo-Trio Test used in the present study.

In a different study by Moretti et al. (2006), extruded rice grains containing $10 \mathrm{mg}$ iron/gram of rice were subjected to Triangle tests to determine whether local women could distinguish the iron-fortified rice from unfortified rice. Four local recipes were tested along with cooked and uncooked rice. The panel was composed of 24 middle-class Indian women. The subjects were blindfolded. The results demonstrated that the fortified and unfortified uncooked rice were indistinguishable. Similarly, in the cooked recipes, meals containing the fortified rice were indistinguishable from the meals containing unfortified rice.

A limitation to this study was the failure to implement the Acceptance Test in individual booths. The evaluation of samples was conducted in rooms reserved at the community centers, which represented partly controlled environments, that is, with 
no physical separation between the panelists. These conditions may have created the opportunity for communication between the participants or other forms of influence on the result. Another limitation was the inclusion of subjects that had less than four years of education, which made it difficult to use the hedonic scale adapted for the Acceptance Test. Thus, according to the profile of the panelists, the Facial Hedonic Scale would have been better adequate for this study.

\section{Conclusions}

Since no significant differences were observed, according to the studied variables, samples of UR rice and conventional rice, the former demonstrates good consumer acceptance suggesting that ferric pyrophosphate, under the concentration discussed, is a preferred inorganic iron salt compound to enrich rice without inducing unacceptable sensory characteristics to the final product. Moreover, rice used as a vehicle for fortification of iron can represent an important alternative to enriched foods since it is deeply rooted in the population's daily dietary culture and eating habits in addition to being widely accessible and affordable by all socio-economic levels of society. Finally, further studies are needed to better evaluate consumer acceptability tests and the bioavailability of this important and widely consumed food in rice-eating populations.

\section{Acknowledgements}

The authors are grateful to the School of Nursing and Nutrition at the Federal University of Minas Gerais for allowing us to conduct part of this study at their dietary laboratory; the Health Secretary of the City of Vespasiano for authorizing us to conduct the study in their community, and they are specially grateful the volunteers for their participation during this study. Finally, we would like to thank the undergraduate students Jaqueline Braga, Jéssica Espósito and Lívia Gonçalves for their assistance in conducting the sensory analysis.

\section{References}

ALLEN, L. H.; GILLESPIE, S. R. What works? A review of the efficacy and effectiveness of nutrition interventions. Manila: ACC/SCN, 2001.

BRASIL. Ministério da Saúde. Agência Nacional de Vigilância Sanitária. Regulamento técnico para fixação de identidade e qualidade de alimentos adicionados de nutrientes essenciais. Portaria n. 31, 13 de janeiro de 1998. Diário Oficial União, Brasília, DF, 13 de janeiro de 1998. Disponível em: <http://www.anvisa.gov.br/legis/ portarias/31_98.htm>. Acesso em: 06 maio 2007.

CARDELLO, H. M. A. B.; CARDELLO, L. Teor de vitamina C, atividade de ascorbato oxidase e perfil sensorial de manga (Mangifera indica L.) var Haden, durante o amadurecimento. Ciência e Tecnologia de Alimentos, v. 18, n. 2, p. 211-217, 1998.

DUTCOSKY, S. D. Análise sensorial de alimentos. Curitiba: Champagnat, 1996.

FOOD AND AGRICULTURE ORGANIZATION OF THE UNITED NATIONS - FAO. Disponível em: <http://www.fao.org/rice2004/ index_en.htm >. Acesso em: 22 abr. 2007.

FERREIRA, A. M. A. Prevenção da anemia ferropriva em lactentes que frequentam creches do município de São Paulo através de uma fórmula láctea infantil fortificada com ferro. 2000.180 p. Tese (Mestrado) - Universidade Federal de Säo Paulo, São Paulo, 2000a.

FERREIRA, V. L. P. Análise Sensorial: testes discriminativos e afetivos. Campinas: SBCTA, 2000b.

HOTZ, C. et al. Efficacy of iron-forfified Ultra Rice in improving the iron status of women in México. Food Nutrition Bulletin, v. 29, n. 2, p. 140-149, 2008.

HURRELL, R. F. Deficiency fortification: overcoming technical and practical barriers. Journal of Nutrition, v. 132, supl. 4, p. 806-812, 2002.

HURRELL, R. F. Preventing iron deficiency through food fortification. Nutrition Reviews, v. 55, n. 6, p. 210-22, 1997.

HURRELL, R. F. et al. Iron fortification of infant cereals: a proposal for the use of ferrous fumarate or ferrous succinate. American Journal Clinical Nutrition, v. 49, n. 6, p. 1274-1282, 1989.

INSTITUTO BRASILEIRO DE GEOGRAFIA E ESTATÍSTICA - IBGE. Pesquisa de orçamentos familiares 2002-2003: aquisição domiciliar alimentar per capita: Brasil e grandes regiões. Disponível em: <http:// www.ibge.gov.br/home/estatistica/populacao/condic aodevida/ pof/2002aquisicao/aquisicao.pdf>. Acesso em: 23 maio 2007.

INTERNATIONAL STANDARD ORGANIZATION. ISO 5497: sensory analysis: methodology: guidelines for the preparation of samples for which direct sensory is not feasible. Genève: ISO, 1982. $4 \mathrm{p}$.

MEILGAARD, M.; CIVILLE, G. V.; CARR, B. T. Sensory evaluation techniques. 4. ed. Boca Raton: Taylor \& Francis, 2006.

MINIM, V. P. R. Análise sensorial: estudos com consumidores. Viçosa: Editora UFV, 2006. 225 p.

MONTEIRO, C. A.; SZARFARC, S. C.; MONDINI, L. Tendência secular da anemia na infância na cidade de São Paulo (1984-1996). Revista de Saúde Pública, v. 34, n. 6, p. 62-72, 2000.

MORAES, M. A. C. Métodos para a avaliação sensorial dos alimentos. 7. ed. Campinas: Unicamp, 1988.

MORETTI, D. et al. Development and evaluation of iron-fortified extruded rice grains. Journal of Food Science, v. 70, n. 5, p. 330-336, 2005.

MORETTI, D. et al. Extruded rice fortified with micronized ground ferric pyrophosphate reduces iron deficiency in Indian school children: a double-blind randomized controlled trial. American Journal of Clinical Nutrition, v. 84, p. 822-829, 2006.

NABESHIMA, E. H. et al. Propriedades tecnológicas e sensoriais de pães fortificados com ferro. Ciência e Tecnologia de Alimentos, v. 25, n. 3, p. 506-511, 2005.

OLIVEIRA, R. S. et al. Magnitude, distribuição espacial e tendência da anemia em pré-escolares da Paraíba. Revista de Saúde Pública, v. 36, n. 1, p. 26-32, 2002.

PHILIPPI, S. T. Nutrição e técnica dietética. Barueri, SP: Manole, 2003.

REILLY, C. Too much of a good thing? The problem of trace element fortification of foods. Trends in Food Science and Technology, v. 7, n. 4, p. 139-142, 1996.

SALGUEIRO, M. et al. Strategies to combat zinc and iron deficiency. Nutrition Reviews, v. 60, n. 2, p. 52-58, 2002.

BRASIL. Ministério do Desenvolvimento Social e Combate á Fome. Tabela Brasileira de Composição de Alimentos: TACO. 2 ed. Campinas: UNICAMP, 2006. 113 p.

WORLD HEALTH ORGANIZATION. Iron deficiency anemia: assessment, prevention, and control: a guide for program managers. Geneva: WHO, 2001. Disponível em: <http://www.who.int/ nutrition/publications/en/ida_assessment_prevention_control. pdf $>$. Acesso em: 30 abr. 2008. 